\title{
Density-dependent reproductive and vegetative allocation in the aquatic plant Pistia stratiotes (Araceae)
}

Flávia Freitas Coelho ${ }^{1}$, Liene Deboni² \& Frederico Santos Lopes ${ }^{2}$

1 Departamento de Biologia Geral, ICB/Universidade Federal de Minas Gerais, CP 486, Belo Horizonte MG, 30161970, Brazil.

2 Departamento de Biologia, Universidade Federal de Mato Grosso do Sul, CP 549, Campo Grande, MS, 79070-900, Brazil; fslopes@nin.ufms.br Corresponding author: Flávia de Freitas Coelho; flaviafc@icb.ufmg.br

Received 16-XI-2004. Corrected 02-VII-2005. Accepted 10-VIII-2005.

\begin{abstract}
Pistia stratiotes is an aquatic macrophyte that grows in temporary-ponds in the southern Pantanal, Brazil. It reproduces both sexually and asexually and is usually observed forming dense mats on the water surface, a condition favored by the plant's vegetative reproduction coupled with an ability for rapid growth. In this study we examined the effect of densely crowded conditions on the production of reproductive and vegetative structures. In addition, we verified whether there is a trade-off between clonal growth and investment in sexual reproductive structures, and whether there is an allocation pattern with plant size. Individual plant biomass and the number of the rosettes producing sexual reproductive structures and vegetative growth structures both increased with density. Increase in plant size resulted in increased proportional allocation to sexual reproductive structures and vegetative growth structures. Allocation of biomass to reproduction did not occur at the expense of clonal growth. Thus, the density response appears as a increase of rosettes producing sexual reproductive structures and vegetative growth structures. Therefore, long leaves and stolons may be adaptive under densely crowded conditions where competition for light is intense. An important aspect in the study of trade-offs is the size-dependency of the allocation patterns .Usually, larger plants produce more biomass. Therefore, larger plants can allocate more biomass to both vegetative and sexual reproduction than smaller plants and thus show a positive correlation between both traits rather than the expected negative one. Rev. Biol. Trop. 53(3-4): 369-376. Epub 2005 Oct 3.
\end{abstract}

Key words: Clonal growth, density-dependence, Pantanal, Pistia stratiotes, reproductive allocation, trade-offs.

The concept of trade-offs between traits is crucial to development of a theory of life history evolution (Stearns 1989). For plants, it is generally assumed that because resources are often limited, allocation among competing functions is mutually exclusive (Loehle 1987). For example, increased allocation to asexual reproduction can occur when allocation to sexual reproduction is reduced or absent (Abrahamson and Caswell 1982, Méndez and Obeso 1993). There is considerable evidence that plant populations differ with respect to the proportion of biomass allocated to reproductive structures in individual plants.
As in terrestrial plants, reproduction in water plants consists of both sexual and asexual mechanisms and possesses three allocation options: growth, vegetative propagation and sexual reproduction. Although the latter two options both produce physiologically independent individuals, sexual reproduction introduces new genetic individuals (genets) to the population, whereas vegetative propagation produces genetically identical clones (ramets) that contribute to the survival and reproductive success of the parent genet (Harper 1977). Production of ramets decreases the risk of genet mortality (Cook 1979) and allows the 
genet to exploit larger areas and new locations, provided that vegetative propagules are widely dispersed (Lovett Doust 1981). As essencial feature of modular construction of many clonal plants species is that ramets ("feeding sites") are located on stolon or rhizomes (plagiotropic stems or "spacers") which project them into habitat space (De Kroon and Schieving 1991).

Several studies have focused measuring the partitioning of biomass to different plant structures, and variations in reproductive effort have been considered as functions of differences in density (Abrahamson 1975, Thompson and Beattie 1981). Reproductive effort is often defined as the proportion of total biomass allocated to reproductive structures and interpreted as representing the carbon allocation of a plant to reproduction (Reekie and Bazzaz 1987). Changes in relative allocation to vegetative propagation and sexual reproduction are sometimes associated with changes in plant size caused by varying plant density (Hartnett 1990, Méndez and Obeso 1993). In many cases, changes in the production of reproductive structures in plants grown at different densities can be explained in terms of sizedependent reproduction of individuals (Weiner 1988, Sakai 1995). According to the model of Samson and Werk (1986), reproductive allocation is expected to increase with increasing plant size. However, a size-dependent pattern of resource allocation may differ among species, because the ecological characteristics of vegetative offspring vary greatly among species (Sato 2002).

In this study, we examined the influence of densely crowded conditons on patterns of biomass allocation in Pistia stratiotes L. (Araceae). It reproduces rapidly through stoloniferous offshoots and is generally considered an aquatic weed (Sculthorpe 1967), with a world-wide distribution. It grows, frequently, in still fresh water in southern Pantanal forming thick mats on the surface. However, its growth is affected by density of plants (Dewalds and Lounibos 1990).

To assess paterns of resource allocation, we measured sexual reproduction (flower and fruit production), and vegetative reproduction (stolons production). Three specifc questions were addressed. (1) Does densely crowded conditions affect length of leaves and stolon, biomass of leaves and reproductive strutctures (RS)? (2) Do trade-offs occur between sexual reproduction and clonal growth? (3) Do allocation patterns vary with plant size?

\section{MATERIALS AND METHODS}

Study species: The stoloniferous, rosetteforming Pistia stratiotes L. (Araceae) is an aquatic macrophyte that grows in temporaryponds in the Southern Pantanal. The species has a pantropical distribution. It reproduces both sexually and asexually and usually observed forming dense mats on the water surface, a condition favoured by the plant's vegetative reproduction coupled with ability for rapid growth (Lallana 1989). Pistia plants produce a rosette of leaves in a alternate spiral phyllotaxis. Vegetative reproduction in floating plants is often linked to the production of supernumerary (accessory) lateral buds i.e., several lateral buds at the one node (Lemon and Posluszny 2000). The flower is creamywhite, small, hidden in the leaf axil, and, like other Araceae, consist of a spathe and spadice (Schulthorpe 1967). The flower grows from the center of the rosette and is surrounded by a hairy bract (Schulthorpe 1967).

Study area: The Pantanal is a vast floodplain in the tropical South America, occupying an area of $137.000 \mathrm{~km}^{2}$ in the upper Paraguay River Basin. Most of the region is in Brazil, with smaller areas to the west in Bolivia and Paraguay. Because of its great extension and toporaphic, climatic and floristic features that characterize each of its areas, a number of subregions have been proposed for the Pantanal. Adámoli (1982) identified 10 sub-regions, which he named Cáceres, Poconé, Barão de Melgaço, Paraguai, Paiaguás, Nhecolândia, Abobral, Miranda e Nabileque. Climate is tropical with a marked wet season. Local 
precipitation is low with an annual average of 972 mm (Amaral Filho 1986).

The Pantanal possess highest richness of aquatic macrophytes world's. This place many ponds may be found densely covered with vegetation which thrives frequently forming thick mats on the surface. They represent, no doubt, the main vegetation biomass and the source most important of primary production in Pantanal (Por 1995).

The present study was conducted in the Miranda and Abobral sub-regions of the Pantanal, in the municipality of Corumbá, Mato Grosso do Sul state, where Universidade Federal de Mato Grosso do Sul maintains

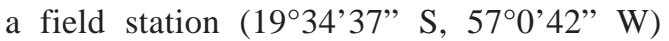
(Figure 1). Plant material was collected in ponds near the station and in others located along the MS-184 road.

Study site: Rosettes of Pistia stratiotes were collected during the period from April to September 1998, at monthly intervals. Rosettes were collected from six ponds. In each month, two of these ponds were chosen: one with low and other high densities of plants. The same pond was sampled only for two following months, due to change in the density of rosettes. In ponds eutrophics, Pistia stratiotes finds optimum conditions for growth. Therefore, it can double their vegetative biomass and to form dense thick mats vegetation rapidly (Dewald and Lounibos 1990, Hollander et al. 1999) as occur in ponds of the Pantanal. The density of the Pistia vegetation at these sites was recorded by estimating the percentage of water surface covered by Pistia stratiotes (low densities: less than $50 \%$ of water surface covered by rosettes; high densities: more than $50 \%$ of water surface covered by rosettes). We considered, due to explained above, the method of estimate of the percentage of the covering of the surface of the water for $P$. stratiotes the most appropriate. This method was already used for Salvinia auriculata in the Pantanal (Coelho et al. 2000). From each pond 30 rosettes were randomly sampled. We collected 360 rosettes in total: 30 rosettes $\times 2$ ponds $\times 6$ months. We measured
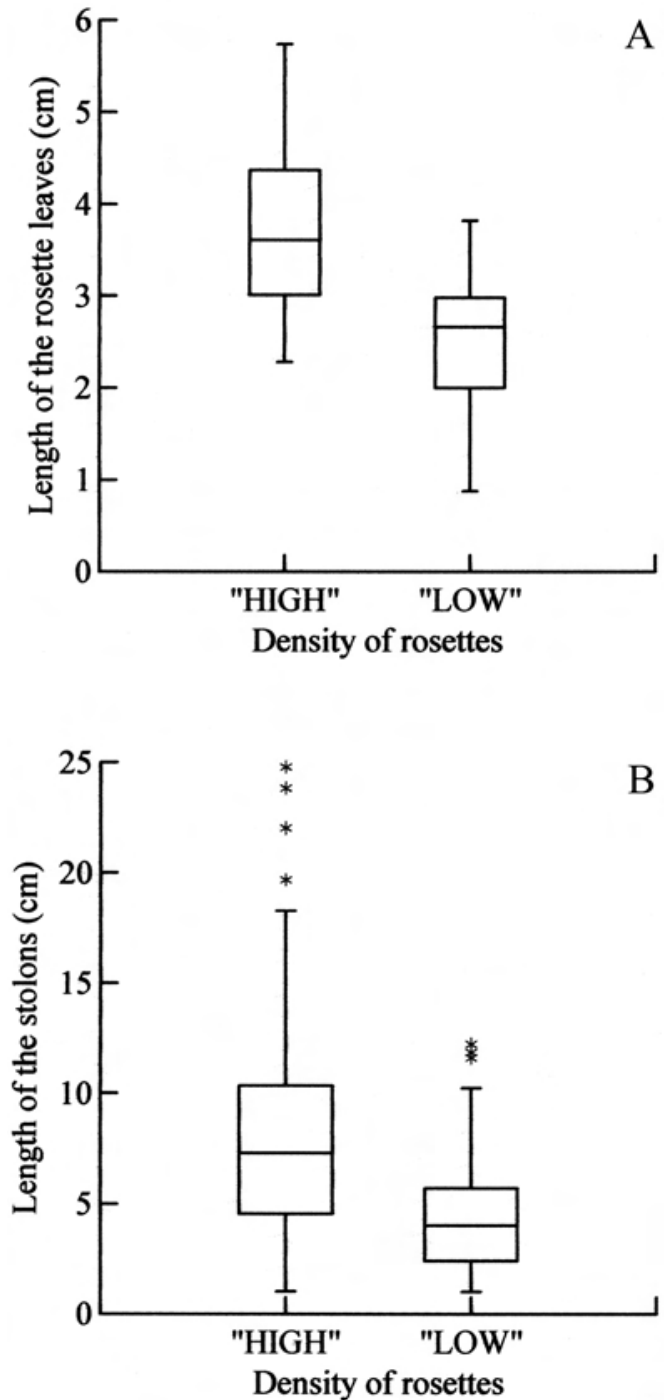

Fig. 1a. Length of the stolons under crowded conditions ( maximum $=24.8 ;$ minimum $=1.02 ;$ mean $=7.7$; median $=$ $6.8 ; \mathrm{SE}=0.4$ ) vs. uncrowded conditions (maximum $=12.3$; minimum $=1.0 ;$ mean $=4.4 ;$ median $=4.02 ; \mathrm{SE}=0.3$ ).

Fig. 1b. Length of the leaves under crowded conditions $(6.5 ; 2.1 ; 4.5 ; 4.6 ; 0.08)$ vs. uncrowded conditions (3.6; $1.04 ; 2.6 ; 2.7 ; 0.06)$.

the number and length of leaves and of stolons, and number of reproductive strutures (flowers and fruits). Dry mass of leaves, of stolons and of reproductive strutures were used as an integral measure of allocation. All plant materials 
were taken back to the laboratory and dried for $48 \mathrm{~h}$ at $80^{\circ} \mathrm{C}$, then weighed.

Data analyses: To test the effect of densely crowded conditions, we compared the length of leaves, length of stolons and biomass of reproductive structures at high and low densities using a Mann-Whitney U-test (Sokal and Rohlf 1981).

To determine whether there were life history tradeoffs, we performed a simple linear regression of stolon allocation and leaf allocation as a function of the biomass of reproductive structures (RS).

To test the effect of the size of rosettes on the reproductive structure and stolons production, we performed a simple linear regression of biomass of reproductive structures (RS), and biomass of stolons as a function of the length of leaves per rosette.

\section{RESULTS}

The densely crowded conditions affected the length of the leaves and stolons (Fig. 1a and b) as well as the production of RS. The rosettes were significantly larger in densely crowded mats both stolons and leaves, respectively ( $\mathrm{U}=$ 707.000; $\mathrm{p}<0.001)(\mathrm{U}=810.500 ; \mathrm{p}<0.001)$.

Flowering of Pistia appears to be markedly enhanced in densely crowded conditions. Pistia Plants in areas with high plant density flowered more profusely (Fig. 2a and b). The production of reproductive structures both number $(\mathrm{U}=895.500 ; \mathrm{p}<0.001)$ and biomass $(\mathrm{U}=898.500 ; \mathrm{p}<0.001)$ were greater under densely crowded conditions.

A significant linear relationship between dry mass of RS and dry mass of rosette leaves $\left(\mathrm{r}^{2}=0.81 ; \mathrm{p}<0.001 ; \mathrm{N}=195\right)$ (Fig. 3a). However, the predicted trade-off between dry mass of RS and stolon allocation was not confirmed $\left(r^{2}=0.006 ; p=0.3 ; N=188\right.$ ) (Fig. 3b).

Reproduction appeared to be closely linked to plant size. Individuals with leaves less than 2 , $8 \mathrm{~cm}$ did not produce any inflorescences, while all individuals larger than $3.1 \mathrm{~cm}$, about $53 \%$
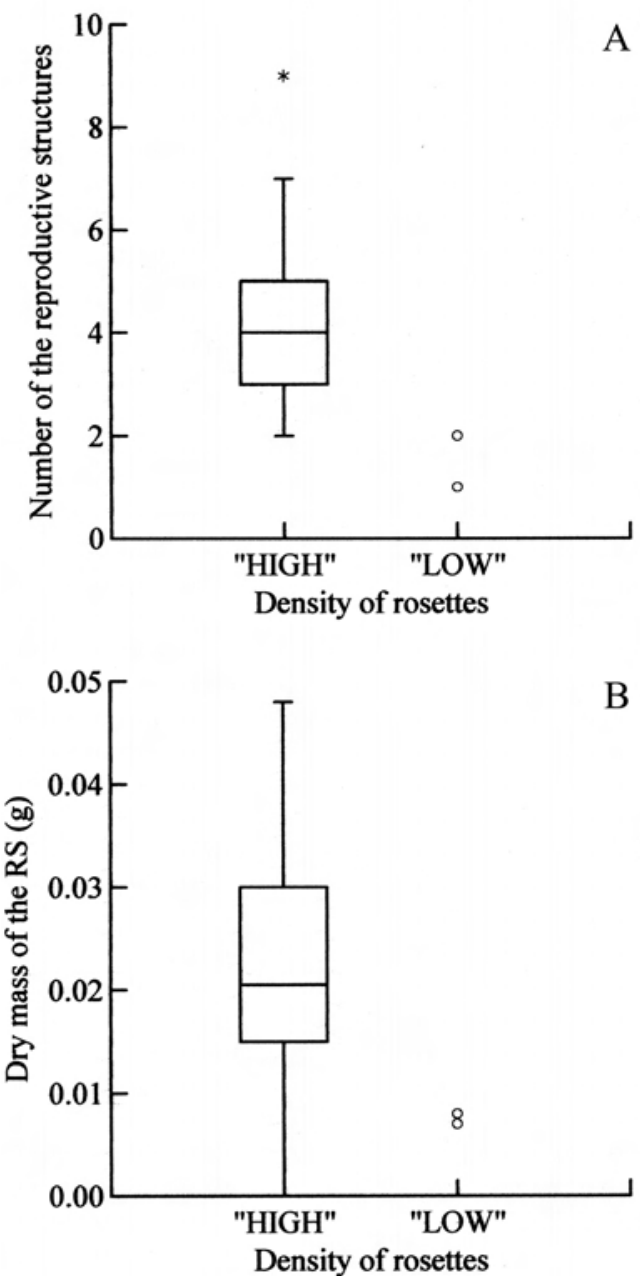

Fig. 2a: Number of reproductive structures under crowded conditions $(10.0 ; 0.0 ; 4.5 ; 4.0 ; 0.2)$ vs. uncrowded conditions $(2.0 ; 0.0 ; 0.03 ; 0.00 ; 0.03)$.

Fig. 2b: Dry mass of reproductive structures under crowded conditions $(0.048 ; 0.000 ; 0.022 ; 0.021 ; 0.001)$ vs. uncrowded conditions $(0.008 ; 0.001 ; 0.000 ; 0.000 ; 0.000)$.

of the rosettes sampled $(\mathrm{N}=360)$, produced at least $0.007 \mathrm{~g}$ of the reproductive structures.

The investment to the two reproductive modes increased with plant size (Fig. 4a and b). A significant linear regression was found between the dry biomass of RS and length of the leaves $\left(\mathrm{r}^{2}=0.8 ; \mathrm{p}<0.001\right)$. There was a tendency for an increase in the biomass of the stolon as a increase on the length of the leaves. 

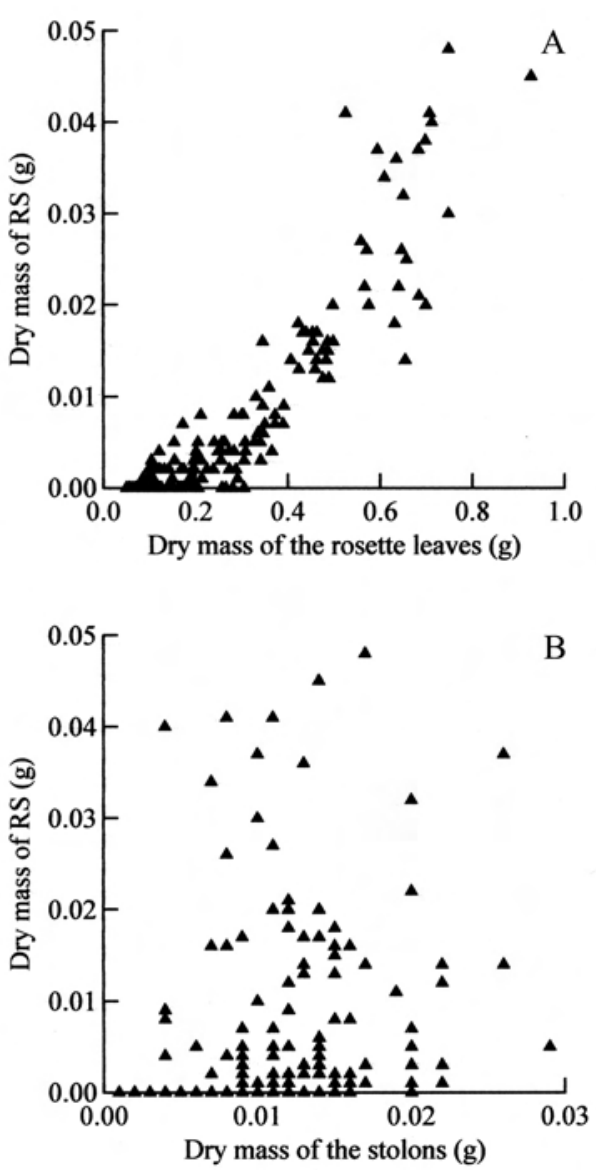

Fig. 3a. Relationship between dry mass of reproductive structures and dry mass of leaves per rosette $\left(r^{2}=0.81\right.$; $\mathrm{p}<0.001 ; \mathrm{N}=195) .(\mathrm{Y}=-0.006 \mathrm{X}+0.05)$.

Fig. 3b. Relationship between dry mass of reproductive structures and dry mass of stolons per rosette $\left(r^{2}=0.006\right.$; $\mathrm{p}=0.3 ; \mathrm{N}=188) .(\mathrm{Y}=0.045 \mathrm{X}+0.009)$.

However, the amount of variation explained by this variable was so small $\left(\mathrm{r}^{2}=0.15 ; \mathrm{p}<0.001\right)$.

\section{DISCUSSION}

\section{Effects of crowded conditions in vegetative structure and $R S$}

Our data showed that there was a stronger effect of densely crowded conditions both on
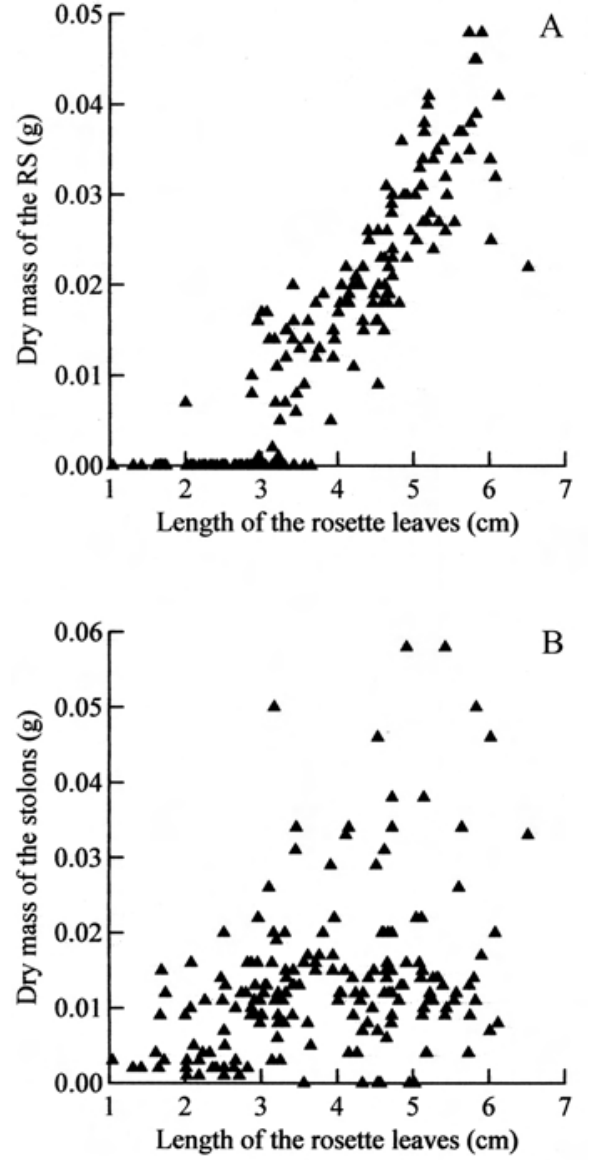

Fig 4a. Biomass allocation to reproductive structures as a function of length of the rosette leaves $\left(r^{2}=0.8 ; p<0.001\right.$; $\mathrm{N}=195)(\mathrm{Y}=-0.024 \mathrm{X}+0.01)$

Fig. 4b. Biomass allocation to stolons as a function of length of the rosette leaves $\left(\mathrm{r}^{2}=0.015 ; \mathrm{p}=0.03\right)(\mathrm{Y}=$ $0.001 \mathrm{X}+0.003)$.

the length of leaves and stolon and biomass of leaves and reproductive strutctures. They are consistent with Abrahamson (1975) prediction that clonal plants should shift to sexual reproduction when density becomes high and the survival probability of further ramets produced locally becomes low. At higher densities local conditions for growth are unfavorable because of crowding. Similar results were also reported in Fragaria virginiana, in which asexual reproduction declined with increased density 
(Holler and Abrahamson 1977). Furthermore, our results also support Eriksson's (1989) hypothesis that the clonal species in which local recruitment mainly depends on vegetative propagation allocates more to sexual reproduction when its ramet density becomes high.

Throughout this paper we have implicitly treated reproductive structures (RS) (flowers and fruit) and stolon as two forms of reproduction. Harper (1977) considers stolons as normal vegetative growth and distinguishes between reproductive and growth forms by asserting that the former must arise from a single cell. Stolon production is viewed as a competitive growth form adapted to resource gathering so that a clone may horizontally exploit the habitat.

Under densely crowded mats stolons of Pistia were larger than in uncrowded conditions. Stolons enable clonal plants to place their ramets, which in Pistia are in shape of rosettes, in different microhabitats (patches) within the environment (De Kroon and Schieving 1991). Such behavior is achieved, mainly, by plasticity in the length of the stolons (De Kroon and Hutchings 1995). At microhabitas where local conditions for growth are unfavourable because of crowding, stolon lenght will be larger which allows clonal plants to arrange their ramets at microhabitats favourable for growth (De Kroon and Hutchings 1995).

Under densely crowded mats we found leaves larger than under uncrowded conditions. According to Sculthorpe (1967), in crowded conditions where competition is acute, will aquatic macrophyte species exhibit larger rosettes. This is a response that allow to the plant maximize leaf the photossynthetic area, important at sites with high density of plants, where competition for light is intense and space is restricted for horizontal growth (Gopal and Goel 1993, Coelho et al. 2000). Leaf construction is a trade-off between maximizing photossynthetic area and avoiding stress (light or nutrient limitation, due to increase in density) (Madsen 1991). Nevertheless, long leaves are likely to be adaptive under competition (van Kleunen et al. 2000).

\section{Trade-offs between production of vegetative structure and RS}

The expectation that life history trade-offs would occur between clonal growth (stolon mass) and sexual reproduction (production of RS) was not upheld. Despite the resource allocation assumption that two modes of propagation are alternatives, i.e. increased allocation to one mode of propagation results in a proportional decrease in the other (Abrahamson and Caswell 1982), Hutchings and Bradbury (1986), show that is not possible assume that the stolon extension necessarily constrain growth and allocation of biomass for other structures of the plant. It is probable that the trade-off between cost-benefit of the production of a structure for the plant to be affected by its function immediate in the plant. Our results are similar to the findings of Lallana (1989), who found a proportion of RS per rosette of Pistia similar to the stolons.

The main mode of propagation of Pistia is via stolon (Lallana 1989), however seed formation seems the only way for this plant to survive under specific circumstances induced by crowding (Hollander et al. 1999). Moreover, dispersal is generally considered a primary function of seeds (Loehle 1987), important in densely crowding conditions. Nevertheless, stolons are capable of a limited but important dispersal of clonal offspring away from the parent ramet (Grace 1993). Even though distances between ramets are not usually great, when combined with a strong capacity for multiplication, this mode of clonal reproduction can result in rapid rates of dispersion (Grace 1993). This effect is enhanced, too, by an increased internode length for plants spreading in a newly colonized habitat (Fahrig et al. 1994).

\section{Plant size and allocation}

In Pistia, resource allocation to different plant activities increased with increasing plant size. As for many perennial plants, Pistia reach to a minimum size before sexual reproduction 
occur. Similar findings have been found in Viola spp. (Thompson and Beattie 1981). Rosettes of Pistia that are above a minimum size of approximately $2.8 \mathrm{~cm}$ do not flower regularly. According to Weiner (1988), individuals plants growing at a range of densities can alter the production of $\mathrm{RS}$ in response to their own size. The pattern of size-dependence with regard to optimal resource allocation among spacers, ramets and seeds varies according to conditions such as path density (Sakai, 1995). Plant size may be the mechanism through which variation in the density is detected and translated into variation in reproductive behavior (Weiner 1988).

\section{ACKNOWLEDGMENTS}

The authors thank Rogério Parentoni Martins, Geraldo Wilson Fernandes and Júlio Louzada for their helpful suggestions on earlier drafts. We are also grateful to Leonardo Viana for his help in the English translation. This study was supported by the Universidade Federal de Mato Grosso do Sul and a grant from CNPq-521746/97-3 whose assistance we gratefully acknowledge.

\section{RESUMEN}

Pistias strariotes es una macrófita acuática que crece en charcas estacionales en el Pantanal sureño de Brasil. Se reproduce tanto sexual como asexualmente y se obsrva generalmente que forma densas parches sobre la superficie del agua, una condicion que favorecida por la reproduccion vegetativa de la planta junto con una habilidad para el rapido crecimiento. En este estudio se examinó el efecto de las condiciones densamente aglomeradas sobre las estructuras reproducctivas y vegetativas. En adicion, se verificó hasta donde hay un intercambio entre el crecimiento clonal y la inversión en estructuras reproductivas, y hasta donde hay un patrón de tranlocación con el crecimiento de la planta. La biomasa individual de las plantas y el número de rosetas productoras de estructuras reproductivas y estructuras de crecimiento vegetativo se incrementan con la densidad. El incremento en el tamaño de las plantas resultó en un incremento proporcional de la asignación hacia estructuras reproductivas y estructuras de crecimiento vegetativo. La asignación de biomasa hacia reproducción no ocurrió a expensas del crecimiento clonal. Así, la respuesta a la densidad parece como un incremento en la producción de rosetas que producen estructuras reproductivas y de crecimiento vegetativo. Por lo tanto, las hojas largas y estolones pueden ser adaptativas bajo condiciones de densamente aglomeradas dond la competencia por la luz es intensa. Un aspecto importante en el estudio de intercambio son los patrones asignación dependientes de la densidad. Usualmente, las plantas más grandes producen más biomasa. por lo tanto, las plantas más grandes pueden asignar más biomasa hacia la reproducción vegetativa y sexual que las plantas pequeñas y así mostraron una correlación positiva entre ambos caracteres.

Palabras clave: Pistias strariotes, Pantanal, crecimiento clonal, densidad, reparto reproductivo, intercambio.

\section{REFERENCES}

Abrahamson, W.G. 1975. Reproductive strategies in dewberries. Ecology 56: 721-726.

Abrahamson, W.G. \& H. Caswell. 1982. On the comparative allocation of biomass, energy and nutrients in plants. Ecology 63: 982-991.

Adámoli, J.1982. O Pantanal e suas relações fitogeográficas com os cerrados; discussão sobre o conceito de "Complexo do Pantanal". Congr. Nac. Bot. 32: 109-119.

Amaral Filho, Z.P. 1986. Solos do pantanal matogrossense, p. 91-103. In Anais do Simpósio De Recursos Naturais e Sócio-econômicos do Pantanal, Corumbá. Embrapa, Brasília.

Coelho, F.F., F.S. Lopes \& C.F. Sperber. 2000. Densitydependent morphological plasticity in Salvinia auriculata Aublet. Aquat. Bot. 66: 273-280.

Cook, R.E. 1979. Asexual reproduction: a further consideration. Am. Nat. 113: 769-772.

De Kroon, H. \& F. Shieving. 1991. Resource allocation patterns as a function of clonal morphology: a general model applied to a foraging clonal plant. J. Ecol. 79: 519-530.

De Kroon, H. \& M.J. Hutchings. 1995. Morphological plasticity in clonal plants: the foraging concept reconsidered. Ecology 83: 532-538.

Dewalds, L.B. \& L.P. Lounibos. 1990. Seasonal growth of Pistia stratiotes in South Florida. Aquat. Bot. 36: 263-275.

Eriksson, O. 1989. Seedling dynamics and life histories in clonal plants. Oikos 55: 231-238. 
Fahrig, L., D.P. Coffin, W.K. Lauenroth \& H.H. Shugart. 1994. The advantage of long-distance clonal spreading in highly disturbed habitat. Evol. Ecol. 8: 172-187.

Gopal , B. \& U. Goel. 1993. Competition and allelopathy in aquatic plant communities. Bot. Rev. 59: 155-208.

Grace, J.B. 1993. The adaptive significance of clonal reproduction in angiosperms: an aquatic perspective. Aquat. Bot. 44: 159-180.

Harper, J.L. 1977. Population Biology of Plants. Academic, London.

Hartnett, D.C. 1990. Size-dependent allocation to sexual and vegetative reproduction in four clonal composites. Oecologia 84: 254-259.

Holler, L.C. \& W.G. Abrahamson. 1977. Seed and vegetative reproduction in relation to density in Fragaria virginiana (Rosaceae). Am. J. Bot. 64: 1003-1007.

Hollander, N.G., I.W. Shenk, S. Diouf, M.J. Kropff \& A. H. Pieterse. 1999. Survival strategy of Pistia stratiotes L. in the Djoudj National Park Senegal. Hydrobiologia 415: 21-27.

Hutchings, M. J. \& I. K. Bradbury. 1986. Ecological perspective on clonal perennial herbs. BioScience 36: 178-182.

Lallana, V.H.. 1989. Aspectos reproductivos del repolito de agua (Pistia stratiotes L.) en ambientes leníticos del río Paraná medio. Iheringia 39: 37-54.

Lemon, G.D. \& U. Posluszny. 2000. Shoot development and evolution in Pistia stratiotes (Araceae). Int. J. Plant Sci. 161: 721-732.

Loehle, C. 1987. Partitioning of reproductive effort in clonal plants: a benefit-cost model. Oikos 49: 199-208.

Lovett Doust, L. 1981. Population dynamics and local specialization in a clonal perennial (Ranunculus repens). 1 The dynamics of ramets in contrasting habitats. J. Ecol. 69: 743-755.

Madsen, J.D. 1991. Resource allocation at the individual plant level. Aquat. Bot. 41: 67-86.
Méndez, M.\& J.R. Obeso. 1993. Size-dependent reproductive and vegetative allocation in Arum italicum (Araceae). Can. J. Bot. 71: 309-314.

Por, E.D. 1995. The Pantanal of Mato Grosso (Brazil). World's Largest Wetlands, p.1-122. In Dumont, H.J. \& M.J.A. Werger (eds.) Monographiae Biologicae. Kluwer Academic, London.

Reekie, E.G. \& F.A. Bazzaz, 1987. Reproductive effort in plants. 1. Carbon allocation to reproduction. Am. Nat. 129: $876-896$.

Sakai, S. 1995. Optimal resource allocation to vegetative and sexual reproduction of a plant growing in a spatially varying environment. J. Theor. Biol. 175: 271-282.

Samson, D.A. \& K.S. Werk. 1986. Size-dependent effects in the analysis of reproductive effort in plants. Am. Nat. 127: 667-680.

Sato, T. 2002. Size-dependent resource allocation among vegetative propagules and male and female functions in the forest herb Laportea bulbifera. Oikos 96: 453-462.

Sculthorpe, C.D. 1967. The Biology of Aquatic Vascular Plants. Edward Arnold, London. 610p.

Sokal, R.R. \& F.J. Rohlf. 1981. Biometry. Freeman, San Francisco.

Stearns, S.C. 1989. Trade-offs in life-history evolution. Funct. Ecol. 3: 259-268.

Thompson, D.A. \& A.J. Beattie. 1981. Density-mediated seed and stolon production in Viola (Violaceae). Am. J. Bot. 68: 383-388.

Van Kleunen, M., M. Fischer \& B. Schimid. 2000. Costs of plasticity in foraging characteristics of the clonal plant Ranunculus reptans. Evolution 54: 1947-1955.

Weiner, J. 1988. The influence of competition on plant reproduction, p. 228-245. In Lovett-Doust, J. \& L. Lovett-Doust (eds.). Plant reproductive ecology: patterns and strategies. Oxford University, Oxford. 